\title{
Extreme Marine Inundations (Tsunamis?) of Coastal Western Australia
}

\author{
Jonathan Nott and Edward Bryant ${ }^{1}$ \\ School of Tropical Environment Studies and Geography, James Cook University, \\ P.O. Box 6811, Cairns, Queensland 4870, Australia \\ (e-mail: jonathan.nott@jcu.edu.au)
}

\begin{abstract}
A B S T R A C T
Along $2500 \mathrm{~km}$ of the Western Australian coast, prehistoric ephemeral marine inundations (storm surges or tsunamis) were much larger than those that occurred since European settlement. The evidence is in the form of shell and coral deposits atop 30-m-high headlands, sand deposits containing large boulders, shell and coral several kilometers inland, and fields of large imbricated boulders across shore platforms. The size of transported boulders and the altitude of these deposits suggest that tsunamis were responsible, not large storm waves. The orientation of boulders reveals paleowave directions. Radiocarbon dating of the deposits suggest three very large tsunamis along this coast during the past millennium.
\end{abstract}

\section{Introduction}

Ephemeral extreme inundations of coasts by marine waters occur as either storm surges or tsunamis. Both forms of inundation leave lithic and/or bioclastic sediments deposited above the highest astronomical tide (Chappell et al. 1983; Atwater 1987; Bryant et al. 1992, 1996; Dawson 1994). However, it is difficult to differentiate between the two along coasts that are subject to both hazards. Tsunami sedimentation is distinguishable where the deposit is emplaced well beyond the reach of storm waves and surge, or it contains clasts too large to be transported by storm waves and surge. Because of the proximity to the convergent plate margin near Indonesia, the Western Australian coast has historically been Australia's most tsunami-prone region, with two 4-6-m-high tsunami run-up inundations occurring over the past 30 yr. However, Western Australia also regularly experiences very intense tropical cyclones that can produce large marine inundations. In order to develop risk assessments of both types of hazards, it is important to derive the longest possible record of each hazard to formulate accurate magnitude/frequency rela-

Manuscript received October 31, 2002; accepted July 1, 2003.

${ }^{1}$ School of Geosciences, University of Wollongong, Northfields Avenue, Wollongong, New South Wales 2522, Australia. tionships. This requires differentiating the two hazards in prehistoric records.

We present results of a detailed survey of paleomarine inundation evidence along more than 2500 $\mathrm{km}$ of the Western Australian coast. The evidence is in the form of wave-transported shell, coral, sand, and boulder deposits atop 30-m-high headlands, elevated sand deposits containing large boulders up to $10 \mathrm{~m}$ above sea level (a.s.l.), shell and coral deposits several kilometers inland, and fields of large imbricated boulders across shore platforms. The elevation of these deposits along with the size of individual clasts suggest that tsunamis, rather than storm waves, were responsible. Radiocarbon dating of the deposits suggests that tsunamis have occurred several times over the past millennium and that coastal communities and infrastructure at these locations may be vulnerable to this hazard in the future.

\section{Geological Indicators of Past Marine Inundations}

Storms. Tropical cyclones are known to transport clasts of broken coral and shell landward to form shingle ridges several meters above the highest tide. Hayne and Chappell (2001) identify several facies including normal beach deposits and storm overwash sediments within such ridges along the 
coast of northeastern Australia. Multiple shoreparallel ridge sequences have provided excellent records of the frequency and intensity of storms over many millennia (Nott and Hayne 2001). Storm deposits also occur in back barrier lagoons; individual sediment layers in them give a long-term frequency of events (Lui and Fearn 1997). Such storm deposits generally do not lie at high levels but are deposited within a few meters of the highest tide. Large lithic clasts can be transported across shore platforms during severe storms (Sussmilch 1912) but as individual clasts, not extensive fields of imbricated boulders.

Tsunamis. Tsunami deposits are better researched compared with those left by storms. Dawson (1994) described their sand and finer deposits; Bryant and Nott (2001) described the suite of geologic fingerprints of tsunamis within a coastal landscape. Fields of imbricated boulders are dramatic tsunami deposits. Tsunami boulder deposits contain one or more of the following characteristics: distinct imbrication of boulder clasts with seaward dips, low variance in alignment of $a$-axes of boulders within a deposit, discrete trains of boulders extending inland, boulders deposited well above storm wave limits, and the presence of marine fauna within the deposit. Such boulder deposits are reported in southeast Australia (Bryant et al. 1996; Young et al. 1996) and along the northeast, northern, and Western Australian coasts (Nott 1997, 2000). Along the northeast coast, some boulders weigh $>200$ tons and measure $>6 \mathrm{~m}$ in length. Imbricated boulders up to $3 \mathrm{~m}$ long and weighing almost 100 tons were deposited atop cliffs $33 \mathrm{~m}$ above present sea level on the tectonically stable coast of southeast Australia (Young et al. 1996).

The most commonly described tsunami deposit is sand laminae within finer-grained facies (Atwater 1987; Dawson et al. 1988). Other forms of sand deposits include chaotic sediment mixtures or "dump" deposits (diamicts). These styles of deposit are often associated with solifluction, ice push, slope wash, or human disturbance (Bryant and Nott 2001). But tsunamis are a likely mechanism along coasts when these other processes can be shown not to have occurred. Some dump deposits lie atop or against the sides of headlands. They are composed of poorly sorted sediments comprising sand, shell, coral, cobbles, and boulders floating in a mud or sand matrix.

Distinction needs to be made between anthropogenic deposits and those left by waves. Deposits of marine shells in dunes can be shell middens left by Aborigines after consuming the shell's host animal. But Aborigines are not known to have used corals for ceremony or consumption or large numbers of lithic fragments except for making stone tools. Stone tools are readily identifiable as chipped or worked fragments. We differentiate wave and anthropogenic deposits by the types of fragments in the deposit. The wave deposits we describe contain shell and coral and numerous lithic fragments, whereas middens contain mostly shell. Wave deposits can also be bedded and show vertical grading.

\section{Evidence for Paleomarine Inundations in Western Australia}

Marine inundation deposits along the Western Australian coast include sand layers with boulder rafts or "floaters," diamicton or "dump" deposits, and fields of imbricated boulders. We discuss six areas: Cape Leveque, Point Samson, Dampier, Karratha, North West Cape, and the southwest coast of Western Australia.

Cape Leveque. Cape Leveque is about $200 \mathrm{~km}$ north of Broome on Australia's northwest coast /fig. 1). Evidence for large marine inundations here include fields of imbricated boulders; sedimentary deposits with marine faunal inclusions atop a $30-\mathrm{m}$ high headland; erosion (plucking) of bedrock and subsequent overturning of the dislodged blocks
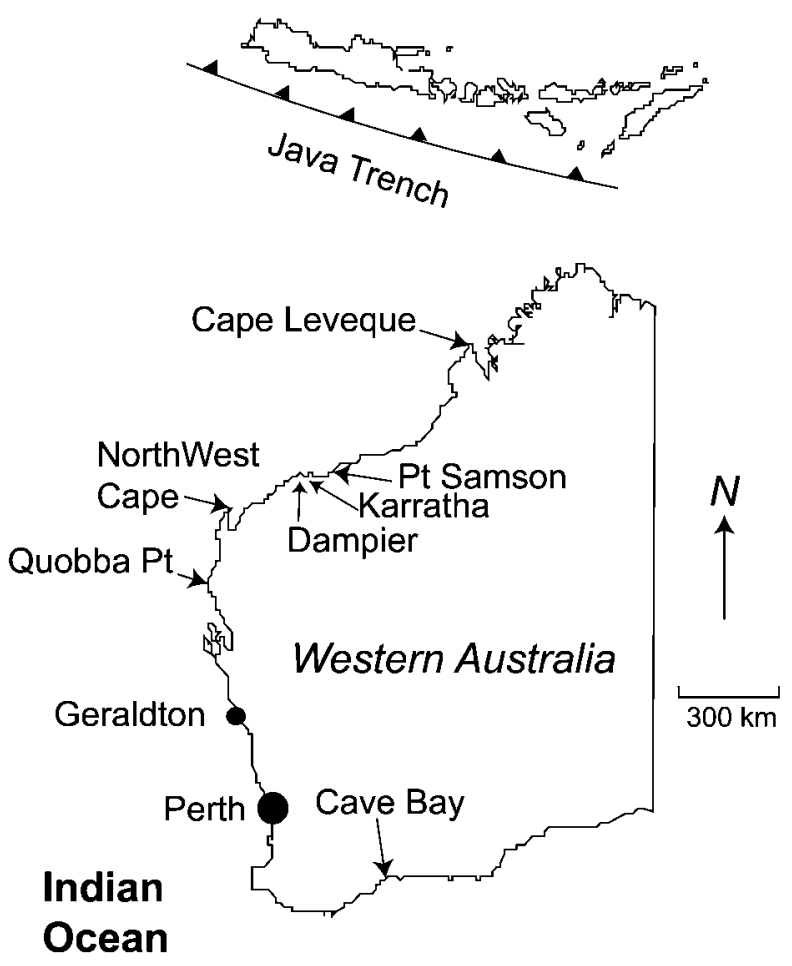

Figure 1. Location map of study sites 


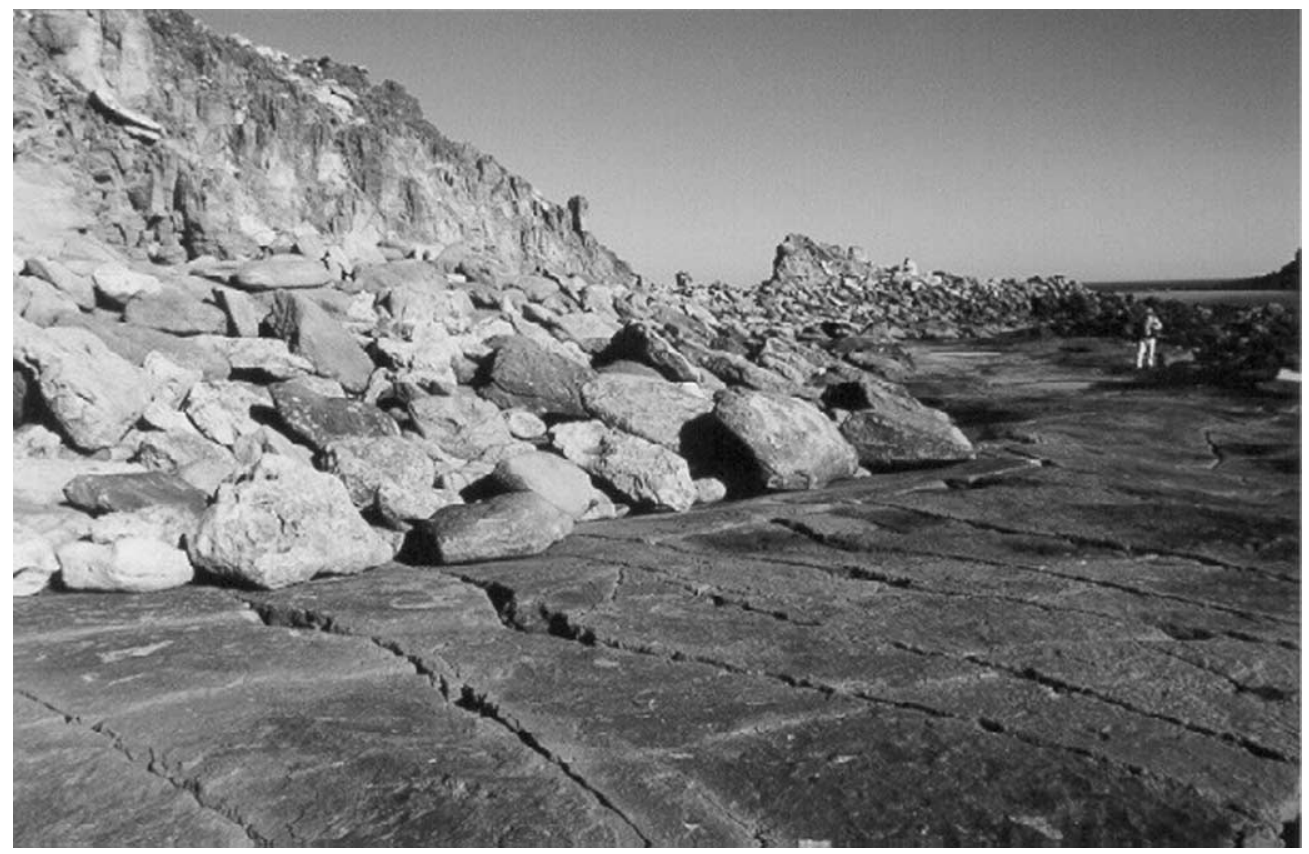

Figure 2. Photograph of boulder field on shore platform at Cape Leveque. View is to west. Note that boulders are imbricated, have different lithology than backing sea cliff, and are absent on seaward part of shore platform.

atop the same headland; and fluvial-like channels, cavetos, and pot holes carved into regolith across the headland.

The boulder field at Cape Leveque includes clasts up to $5.5 \mathrm{~m}$ ( $a$-axis) and $4 \mathrm{~m}$ ( $b$-axis). They have been transported across the shore platform and deposited at the base of the headland (figs. 2, 3). Most boulders are imbricated with seaward dips and have their $a$-axes aligned parallel to shore. The imbrication and alignment record the refraction of the waves around an island $300 \mathrm{~m}$ offshore. The shoreparallel alignment on two sides of the headland differ by about $90^{\circ}$. Boulders on the west side dip west, and those on the north side dip north.

The headland at Cape Leveque is composed of deeply weathered, saprolitic, horizontally bedded Cretaceous siltstone and sandstone. The base of weathering is at the level of the shore platform, which consists of the unweathered part of the rock unit (figs. 3, 4). Many boulders at the headland base are unweathered Cretaceous strata. This suggests they must have come from the shore platform, not from collapse of the headland cliff.

The boulders accumulated at the headland's base where the transporting velocity of the flow was checked. Seaward of the boulder field, the shore platforms are largely devoid of boulders. In places, joint-bounded blocks have been partly lifted, and these blocks now rest with one edge, usually the landward edge, on the shore platform and the remainder of the block sitting within the cavity from which it came. These blocks are often much larger than those plucked and transported into the main boulder field. The velocity of the flow responsible must not have been sufficient to entrain these blocks completely. Possibly, the boulder field resulted from more than one event, perhaps a series of them.

Waves also appear to have topped the headland above the boulder field. A layer of porcellanite sits 20-25 $\mathrm{m}$ a.s.l. near the crest of the headland. ("Pocellanite" is a local term for a silicious rock that forms within a saprolite profile by silica precipitation during the weathering process.) The porcellanite here is $30-100 \mathrm{~cm}$ thick and, like the original Cretaceous strata, is horizontally bedded. It forms horizontally bedded caprock on hills and mesas of Cretaceous strata throughout tropical northern Australia. But today, this horizontal strata is fractured, and individual blocks have been overturned or stand on end partially buried in the weathered red soil (fig. 5). It is difficult to conceive how pedogenic processes could account for the present orientation of the blocks because there is no evidence for vertical shearing within this soil as a result of the expansion and contraction of clays, nor is there evidence for karst processes occurring within the weathering profile that could cause the porcellanite 


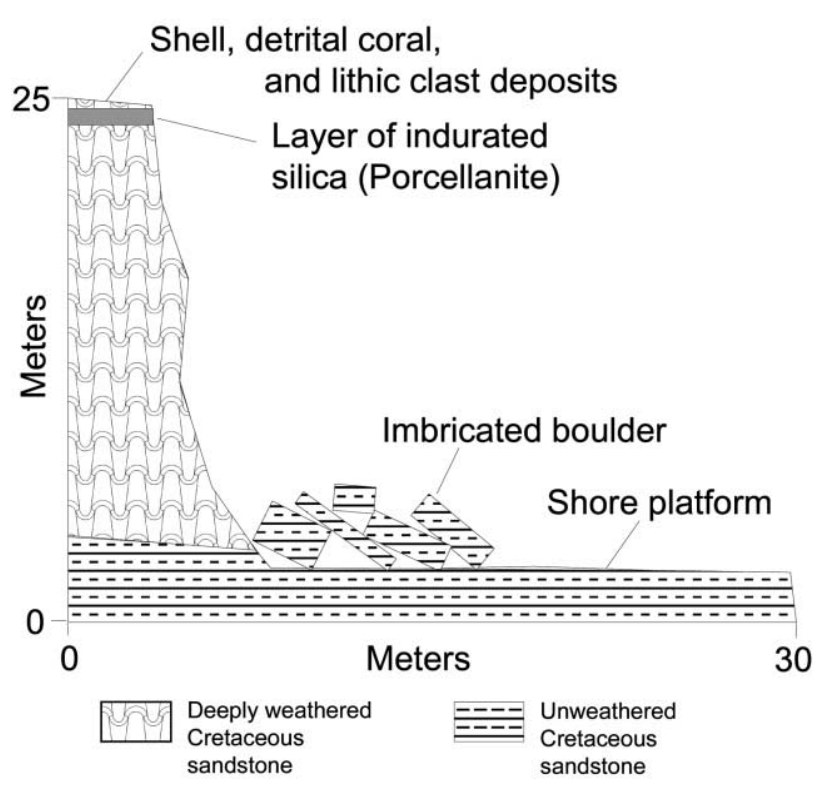

Figure 3. Cross section of headland and shore platform at Cape Leveque.

layer to slump. It is more likely that these rocks were overturned by fluid flow over the headland crest.

Other evidence supports this hypothesis. A channel network deepens and widens eastward across the headland, suggesting that waves overran the headland from the west-northwest. The main channel on the northern side of the headland is $5-6 \mathrm{~m}$ across and as deep as $3 \mathrm{~m}$. Minor tributaries feed into the channel head. Clasts of the porcellanite lie within the drainage channel. Various species of marine shells (Melo amphora, Phasianell sp.), oysters, and coral fragments are scattered across the headland. Dunes of soil weathered from the Cretaceous strata also contain gravel derived from the shore platforms, as well as shell and coral. These dunes sit on a section of the headland about $30 \mathrm{~m}$ a.s.l., above the general level of the dislodged porcellanite layer and the wave overwash channels. Farther south along the western edge of the headland, drainage seems to have been toward the southwest. Here, a network of channels deepen up to $12 \mathrm{~m}$ and widen in the direction of flow. The channels are carved into the weathered but still consolidated Cretaceous strata (fig. 6). The channel walls have well-developed cavetos (scoop-shaped features in channel walls), and potholes a few meters deep are numerous. In the same part of the headland, vegetation has been removed, and an obvious trim line runs south along the west side of the headland. Today, no vegetation grows west (seaward) of this trim line. Yet clearly, vegetation used to be here because abundant iron-indurated root casts occur in the upper soil layer.

Wave-transported sediment at the back of the beach, $400 \mathrm{~m}$ northeast of the headland, includes dunes up to $8 \mathrm{~m}$ high. These dunes contain abundant angular to rounded gravel of Cretaceous sandstone and porcellanite from the headland, together with a variety of species of shells including oysters and coral fragments. The evidence at Cape Leveque suggests the following sequence of events: (1) waves ran up over the headland to $20-30 \mathrm{~m}$ a.s.l., stripped several meters of orange sandy regolith, and maybe also disrupted the porcellanite layer and created boulders of this material; (2) there was partial burial of these boulders, either in this event or a later one, and deposition of shell- and gravel-rich sand dunes at $30 \mathrm{~m}$ a.s.1; (3) channels cut below the level of the high gravel- and shell-rich dune. The erosion of these channels may have been contemporaneous with deposition of sediments on the headland.

Point Samson. There is also evidence for extreme marine inundations at Point Samson, approximately $800 \mathrm{~km}$ south of Cape Leveque. A diamict just south of the main settlement (fig. 7) is $2-4 \mathrm{~m}$

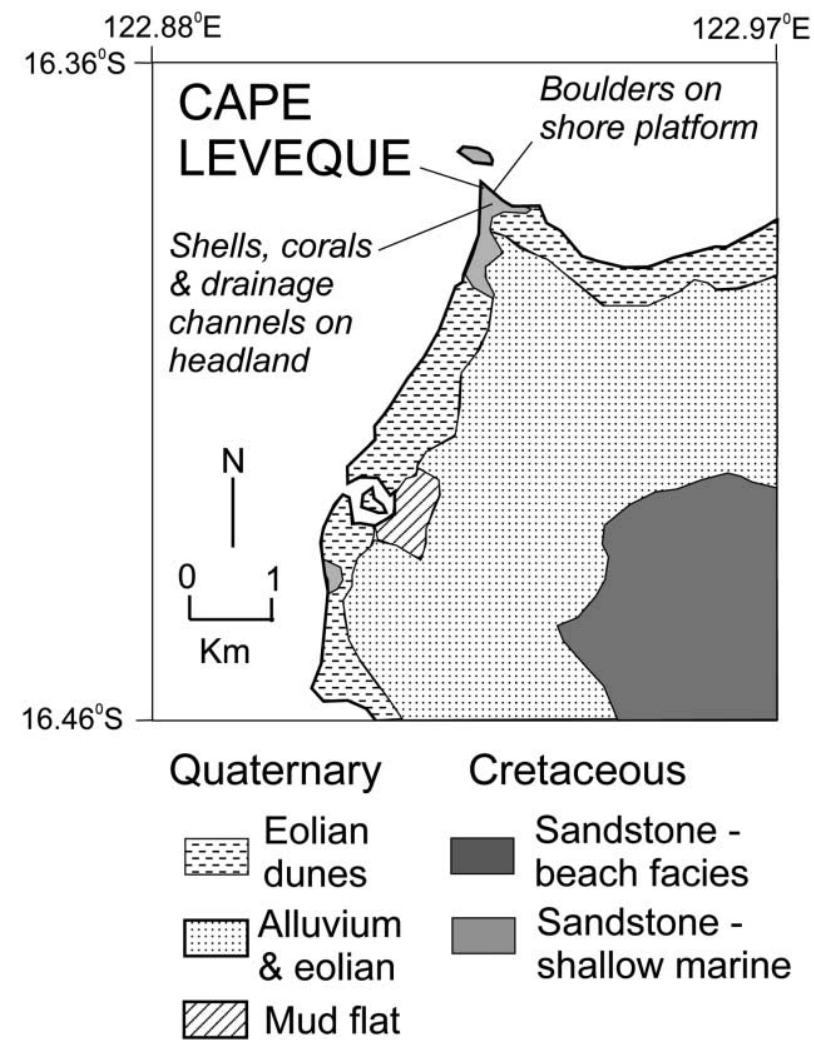

Figure 4. Geologic map of Cape Leveque 


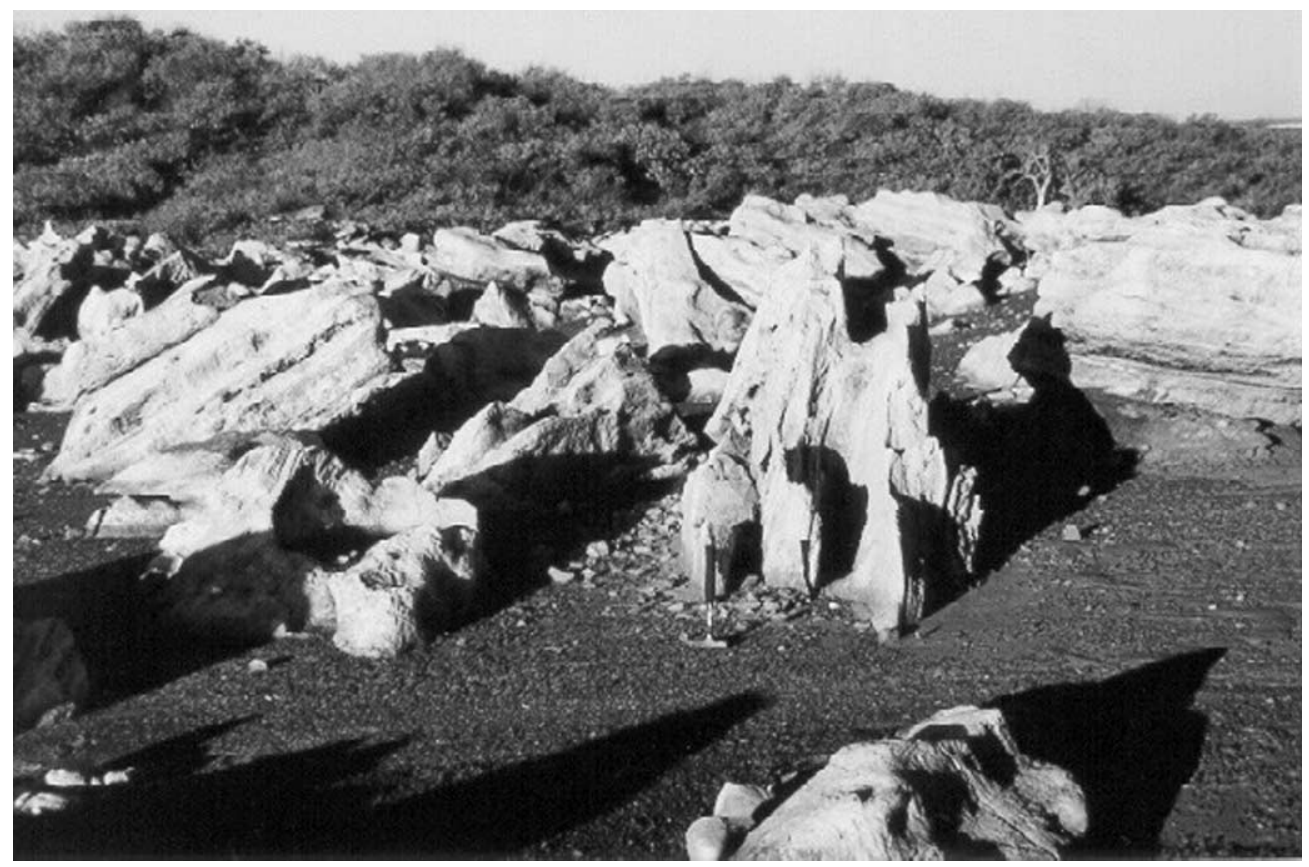

Figure 5. Overturned blocks of porcellanite on top of headland, Cape Leveque. The bedding structures were horizontal until disturbed by overwashing waves.

thick and overlain by eolian sands. The diamict contains angular gravel of banded iron formation as long as several centimeters and large wellrounded basalt boulders as long as $1.5 \mathrm{~m}$. The boulders are supported by medium- to coarse-grained sands and sit as "floaters" (fig. 8). These boulders have been transported at least $10 \mathrm{~m}$ a.s.l. and deposited as part of a chaotic, poorly sorted sediment. Shells, some of which are articulated, and clasts of coral lie within this unit.

Articulated shells also lie 10-13 m a.s.l. around the northern and western sides of a bedrock hill 2 $\mathrm{km}$ inland at Point Samson (fig. 7). More than $40 \%$ of the deposit is composed of articulated bivalves (Katelysia sp.). Probably many other shells were originally articulated but have been subsequently broken by humans and animals. These shells abound here, and the top of the deposit occurs within 12-13 $\mathrm{m}$ a.s.l. around the side of the hill. Species of other marine shells lie here but no coral. These shells were not deposited by humans as a midden because the molluscs inside were not consumed (because the shells are articulated). There is no evidence that these shells have been burnt and opened on a fire, unlike shells in Aboriginal middens. Shells lie on other bedrock hills at Point Samson between 8 and $13 \mathrm{~m}$ a.s.l. In several of these deposits, the shells are too small to have been used as food, further evidence that they did not accumulate as Aboriginal middens.

Wave-emplaced boulder deposits lie along the coast just north of the diamicton deposit at Point Samson. These boulders are as large as $6.2 \mathrm{~m} \times$ $5.3 \mathrm{~m} \times 4.5 \mathrm{~m}$. The seaward dip of these imbricated boulders suggests that they were deposited by waves from azimuth $35^{\circ}$. Dunes on the coast beside the boulder fields rise to $10 \mathrm{~m}$ a.s.l. and contain abundant marine shell and angular gravel. They, too, must have been emplaced or modified by large waves.

Dampier and Karratha. Dampier lies $100 \mathrm{~km}$ west-southwest of Point Samson. Hearson Cove near Dampier contains various sedimentary deposits that seem wave emplaced (fig. 9). At the southern end of Hearson Cove lies a dune 8-10 m high and $150 \mathrm{~m}$ inland. The dune abuts a hill of mafic intrusive and volcanic blocks that appear to have been derived as core stones. The dune is composed of fine- to medium-grained quartz, marine sand with abundant marine shells, and coral fragments, as well as basalt gravel and small boulders. It is possible that the lithic clasts were derived from the adjacent hill by slope processes, but this cannot be the case for the marine shells and coral clasts.

The headland at the southern end of this bay is composed of mafic intrusives and volcanics, acid 


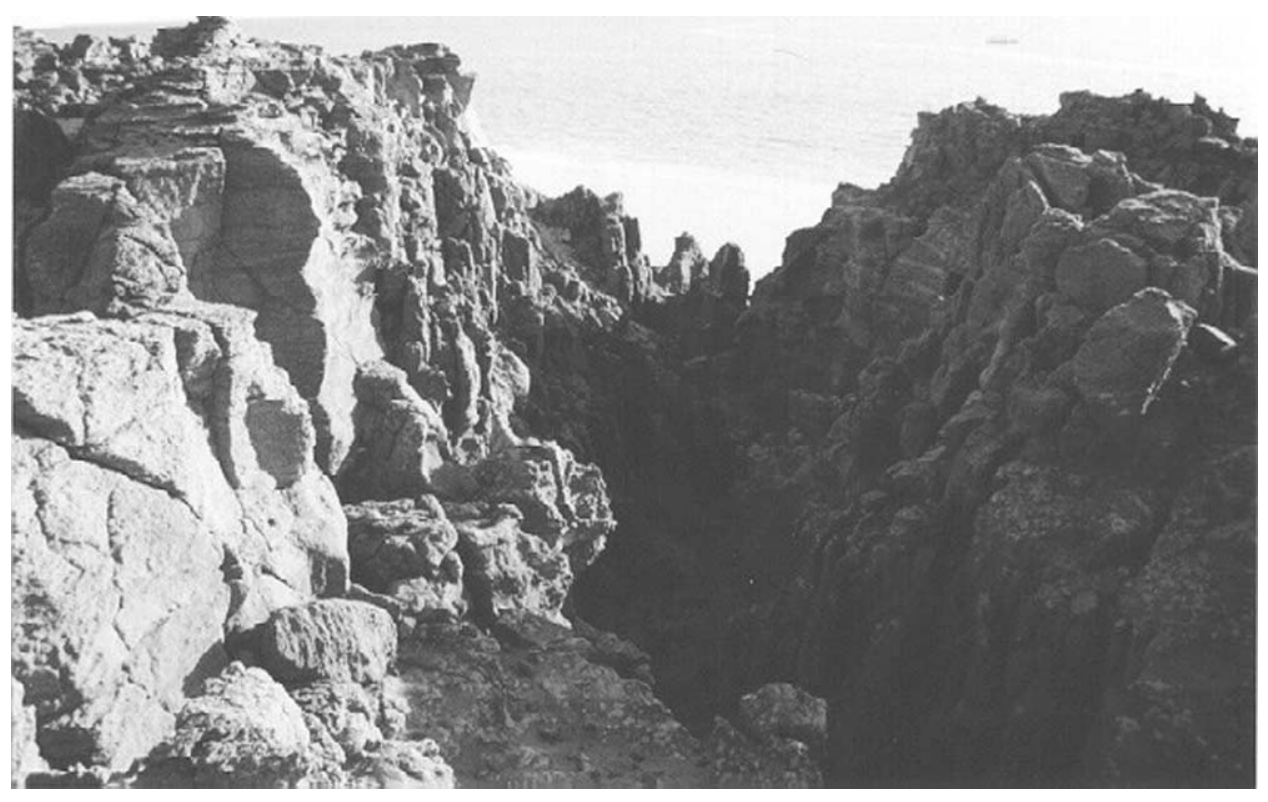

Figure 6. Channels carved in to crest of headland, Cape Leveque

intrusives, and metamorphosed mafic intrusives (fig. 10). These lithologies crop out as a series of vertical units along the length of the headland. Boulders, typically $3.5 \mathrm{~m} \times 2.5 \mathrm{~m} \times 1.0 \mathrm{~m}$, that were derived from these units lie along the shore platform at the base of the headland. Their present positions relative to their host outcrop show they have been transported by waves. Figure 10 shows that the western or shoreward end of the headland is composed of acid intrusives but that the boulders on the adjacent shore platform are composed of acid intrusives and mafic extrusives and metamorphics. Outcrops of these latter two lithologies occur 70$110 \mathrm{~m}$ farther east or seaward. The mafic and metamorphic boulders therefore could not have arrived at their present positions from slope processes alone but must have been transported more than $100 \mathrm{~m}$ along the shore platform by waves. Boulders of particular lithologies do not lie east (seaward) of their host outcrop in the adjacent headland, except for one metamorphic boulder (fig. 10). Thus, the metamorphic boulders lie on the shore platform opposite their host outcrop and then farther west, not generally east. This suggests that the boulders were originally derived via slope processes from this metamorphic unit in the headland and then transported shoreward by waves. The boulders also grade in size with distance west from their source. The metamorphic boulders are largest opposite the outcrop and become progressively smaller toward the western end of the shore platform. This grading seems to be due to a diminution in flow competence because the boulders do not appear to have reduced in size westward (landward) as a result of breakage.

At Karratha, a large sand ridge or dune, $200 \mathrm{~m}$ long and extending to $10 \mathrm{~m}$ a.s.l., contains abundant species of marine shell, coral, and angular to rounded lithic gravel. This ridge is asymmetric, and the steep side faces the ocean; perhaps storm waves eroded the seaward base. The shell, coral, and rock fragments are bedded within the sand ridge, not just scattered across its surface. Large waves have clearly built this ridge, but the number of events is uncertain. These waves have extended inland behind this ridge for at least $1 \mathrm{~km}$, where isolated marine shells and coral fragments lie adjacent to outcrops of bedrock.

North West Cape. North West Cape has evidence of waves washing inland for several hundreds of meters. Near Learmonth on the east side of the Cape, at least seven longitudinal desert dunes running parallel to shore have been overtopped by waves that left fragments of coral, marine shell, and cobbles. These inclusions generally lie about $1 \mathrm{~m}$ below the surface of the dune on top of a slightly indurated calcareous layer visible within shallow blowouts. They must have been deposited on the surface during a period of dune stability. Subsequent eolian reworking deposited a surface layer of sand on top of the paleowave deposit. Elsewhere along this section of coast, marine shells, coral, and 


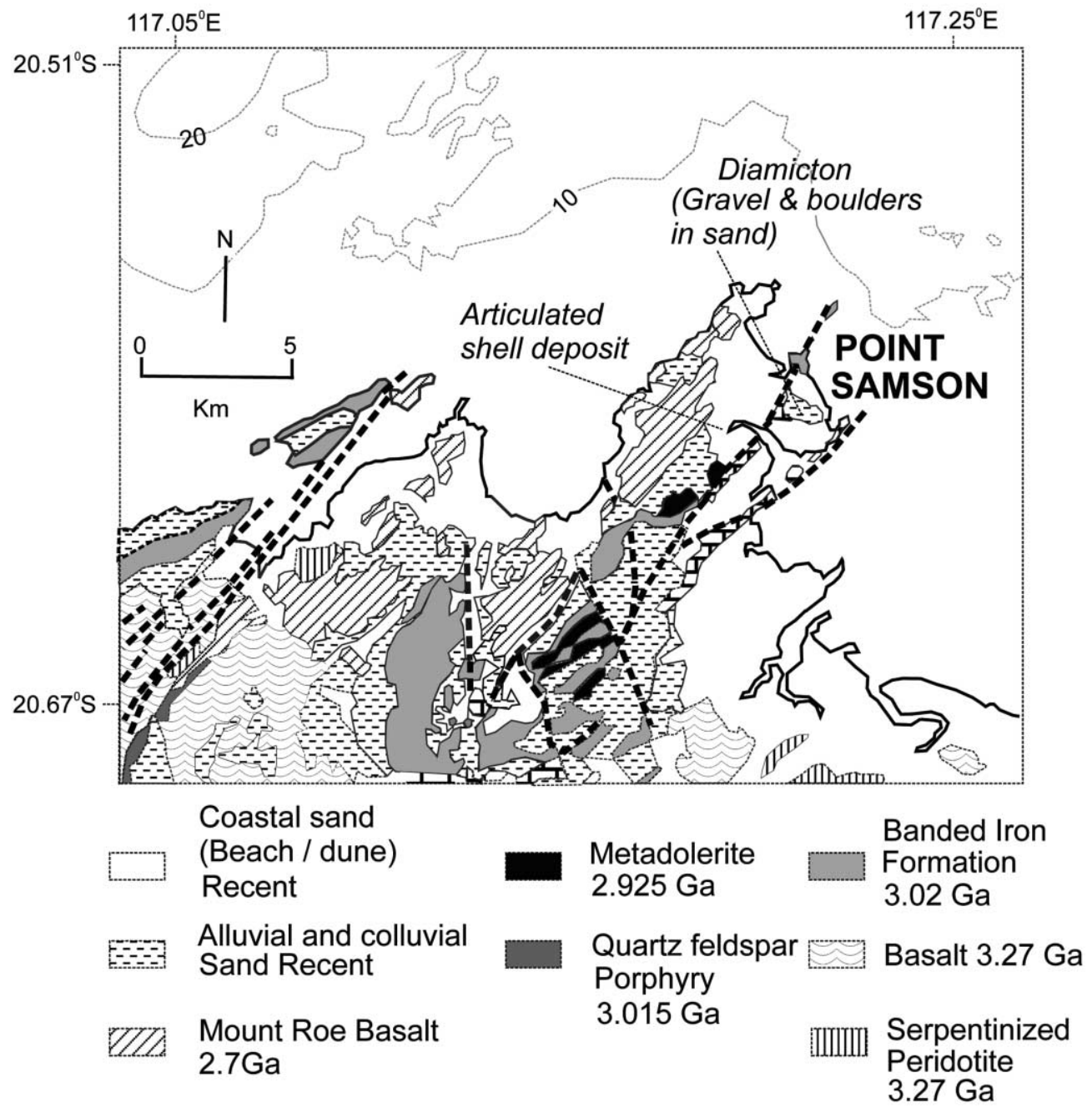

Figure 7. Geologic map of Point Samson

lithic fragments are bedded within the upper part of coastal dunes between 10 and $15 \mathrm{~m}$ a.s.l. Coral and shells also lie scattered for more than $1 \mathrm{~km}$ inland across low plains behind these dunes.

Southwest Coast. South of North West Cape, evidence for large wave events diminishes, but it is not absent. Two notable sites occur at Quobba Point, near Carnarvon, and Cave Bay on the southwest coast of Western Australia. Large boulders (5 $\mathrm{m}, b$-axis) have been tossed and scattered across a shore platform carved from horizontally to subhorizontally bedded sandstone with occasional conglomerate lenses. An island (at high tide) has much larger boulders strewn across it. Most of them occur on the east (mainland) side of the island, where the largest examples have $b$-axis lengths of $6 \mathrm{~m}$. These boulders have been deposited by waves and are not exhumed or left standing as residuals following deep weathering. This is clear because in many boulders, the bedding orientation discords with underlying bedrock bedding.

At Cave Bay, a very large granite boulder, measuring $3 \mathrm{~m} \times 3 \mathrm{~m} \times 2.5 \mathrm{~m}$, has been transported alongshore and now sits on an outcrop of beach rock (sandstone; fig. 11). The nearest source of granite crops out $200 \mathrm{~m}$ alongshore at the south end of the bay. The granite boulder could not have fallen from the cliffs of eolianite behind.

\section{Origin of the Paleowaves}

Two lines of evidence can differentiate the effects of storm waves and surge from tsunamis: the height of the sediment deposited above sea level and the size of the transported material. The first assumes 


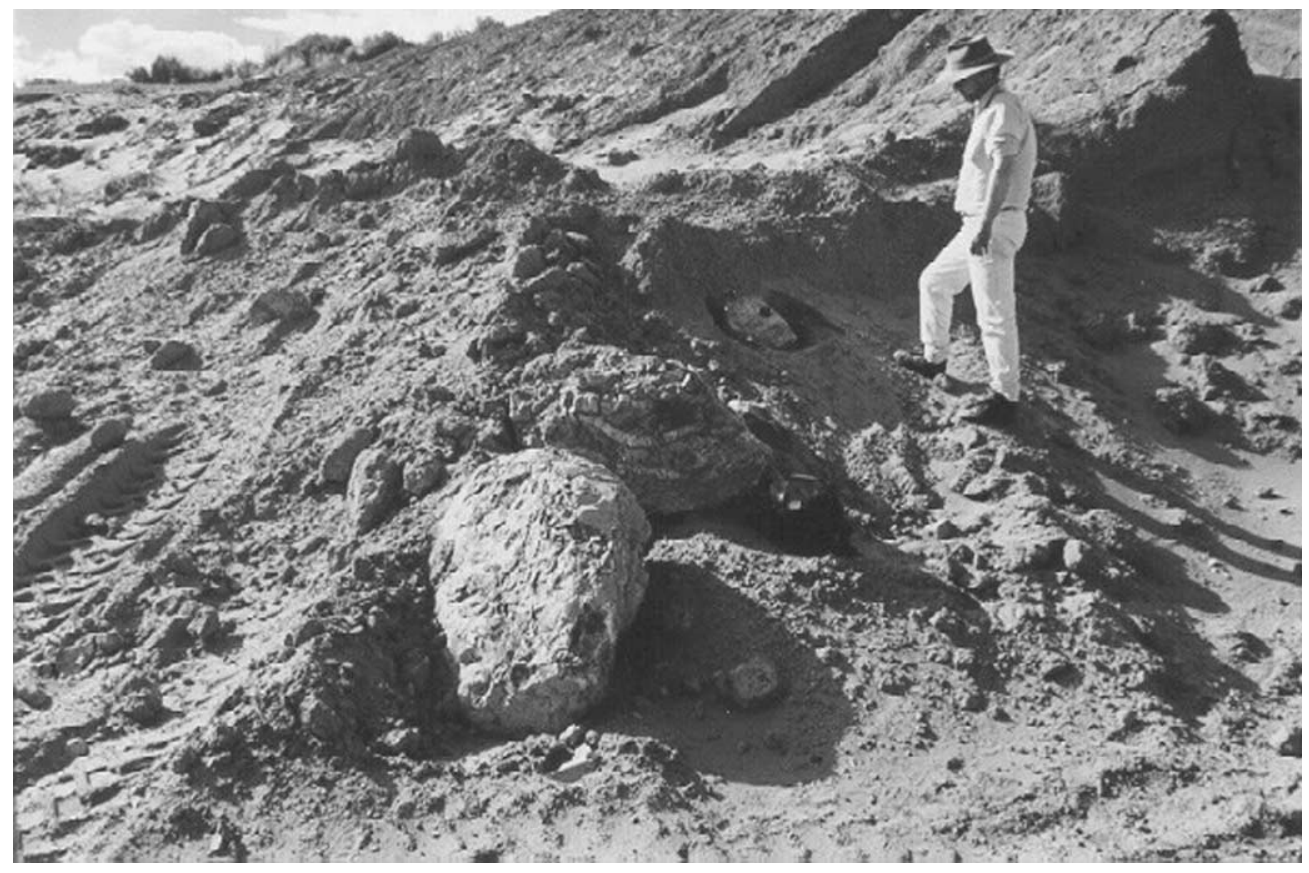

Figure 8. Basalt boulder floaters within dump deposit at Point Samson. Boulders are entirely supported by sand matrix.

that tsunamis are capable of attaining much higher run-up elevations than storm-induced inundation. Storm waves have been known to toss clasts of coral and relatively small rocks many tens of meters onto cliff tops at locations where the water depths immediately offshore are deep enough to support very large wave heights. Before breaking and dissipating their energy, wind-generated waves require water depths about 1.2 times their wave height. Where water depths are shallow, large storm waves will break offshore unless they are accompanied by a substantial storm surge. However, there is a thermodynamic limit to the size or intensity attainable by a tropical cyclone in a given region (Holland 1997), and the same must therefore be true of surge height.

The most intense historic tropical cyclone to cross the Australian coast occurred in March 1999 at North West Cape. This storm produced a maximum run-up (inundation) level of about $5 \mathrm{~m}$ above the high-tide level in this region. Tropical Cyclone Barry crossed the Queensland (northeast Australia) coast in 1996 and produced a peak inundation level of about $6 \mathrm{~m}$. These are the maximum confirmed run-up heights by historic tropical cyclones in Australia. Possibly larger events occurred before European settlement of the continent. It is unlikely that such inundations would have exceeded $10 \mathrm{~m}$, except maybe in extraordinary circumstances where surges may have been funneled and amplified. Therefore, run-up heights of $30 \mathrm{~m}$ at Cape Leveque seem far beyond the physical limits of a tropical cyclone because of the shallow water offshore and the thermodynamic limit of such storms.

Boulders transported by tsunamis can be differentiated from those deposited by storm waves. Tsunamis can transport much larger boulders at the shore than can storm waves. Storm waves are limited in their transporting capacity because of their much lower velocity than that of tsunamis and by the depth of water required to sustain a storm wave upon breaking. But tsunamis can surge across a dry bed or shore.

Hydrodynamic equations determined by Nott (1997) ascertain both storm and tsunami wave heights at the shore capable of transporting (overturning) boulders of a given size (table 1). The storm wave equation referred to a wave at breaking point. Nott's equations relate three forces-drag, lift, and restraint-and incorporate the effect of buoyancy acting on a boulder of given shape with the velocity of the breaking wave. These equations are revised here to incorporate an inertial force along with the drag and lift forces. They also take a more conservative approach to storm wave velocity. 
The revised hydrodynamic transport equation takes the form of

$$
\mathrm{Fd}+\mathrm{Fl}+\mathrm{Fm} \geq \mathrm{Fr}
$$

where

$$
\begin{aligned}
\mathrm{Fd} & =\left[0.5 \rho_{\mathrm{w}} \mathrm{Cd}(a c) u^{2}\right] c / 2, \\
\mathrm{~F} l & =\left[0.5 \rho_{\mathrm{w}} \mathrm{Cl}(b c) u^{2}\right] b / 2, \\
\mathrm{Fm} & =\rho_{\mathrm{w}} \mathrm{Cm}(a b c) \ddot{u}, \\
\mathrm{Fr} & =\left(\rho_{\mathrm{s}}-\rho_{\mathrm{w}}\right)(a b c) g(b / 2),
\end{aligned}
$$

where $\mathrm{Fd}=$ drag force movement, $\mathrm{Fl}=$ lift force movement, $\mathrm{Fm}=$ inertia force, $\mathrm{Fr}=$ restraining force movement, $\rho_{\mathrm{w}}=$ density of water at $1.02 \mathrm{~g} /$ $\mathrm{mL}, \rho_{\mathrm{s}}=$ density of boulder at $2.4 \mathrm{~g} / \mathrm{cm}^{3}, \mathrm{Cd}=$ coefficient of drag $=2, \mathrm{Cl}=$ coefficient of lift $=$ $0.178, g=$ gravitational constant,$V=$ volume of boulder, $\ddot{u}=$ instantaneous flow acceleration, $u=$ flow velocity/bore celerity, $a=a$-axis of boulder, $b=b$-axis of boulder, and $c=c$-axis of boulder.

Equation (1) can be rearranged and expressed as

$$
\mathrm{Fd}+\mathrm{Fl} \geq \mathrm{Fr}-\mathrm{Fm}
$$

Incorporating equations (2), (3), (4), and (5) into equation (6) and solving for $H$ (height of a wave at the shore and in the case of a storm wave, at breaking point) gives

$$
\begin{gathered}
0.5 \rho_{\mathrm{w}} u^{2} 0.5\left[\mathrm{Cd}\left(a c^{2}\right)+\mathrm{Cl}\left(b^{2} c\right)\right] \\
\geq 0.5\left(\rho_{\mathrm{s}}-\rho_{\mathrm{w}}\right) a b^{2} c g-\operatorname{Cm} \rho_{\mathrm{w}} a b c \ddot{u},
\end{gathered}
$$

and transposing $u^{2}$ and simplifying gives

$$
\begin{aligned}
& u^{2} \geq \frac{0.5\left(\rho_{\mathrm{s}}-\rho_{\mathrm{w}}\right) a b^{2} c g-\mathrm{Cm} \rho_{\mathrm{w}} a b c \ddot{u}}{0.5 \rho_{\mathrm{w}} 0.5\left[\mathrm{Cd}\left(a c^{2}\right)+\mathrm{Cl}\left(b^{2} c\right)\right]}, \\
& u^{2} \geq 2 \frac{\left[\left(\rho_{\mathrm{s}}-\rho_{\mathrm{w}} / \rho_{\mathrm{w}}\right) a b^{2} c g-2 \mathrm{Cm}(a b c) \ddot{u}\right]}{\left[\mathrm{Cd}\left(a c^{2}\right)+\operatorname{Cl}\left(b^{2} c\right)\right]}, \\
& u^{2} \geq 2 \frac{\left[\left(\rho_{\mathrm{s}}-\rho_{\mathrm{w}} / \rho_{\mathrm{w}}\right) a g-2 \mathrm{Cm}(a / b) \ddot{u}\right]}{\left[\mathrm{Cd}\left(a c / b^{2}\right)+\mathrm{Cl}\right]},
\end{aligned}
$$

because $u=\delta(g H)^{0.5}$ and $u^{2}=\delta g H$. Substituting $u^{2}$ for $\delta g H$, where $\delta$ is a variable whose value depends on the velocity of the particular wave type (i.e., tsunami or storm wave), gives

$$
\delta g H \geq \frac{\left[\left(\rho_{\mathrm{s}}-\rho_{\mathrm{w}} / \rho_{\mathrm{w}}\right) 2 a g-4 \mathrm{Cm}(a / b) \ddot{u}\right]}{\left[\mathrm{Cd}\left(a c / b^{2}\right)+\mathrm{Cl}\right]},
$$

and solving for $H$ (height of a wave at the shore and in the case of a storm wave, at breaking point) gives

$$
H \geq \frac{1 / \delta\left[\left(\rho_{\mathrm{s}}-\rho_{\mathrm{w}} / \rho_{\mathrm{w}}\right) 2 a-4 \mathrm{Cm}(a / b)(\ddot{u} / g)\right]}{\left[\mathrm{Cd}\left(a c / b^{2}\right)+\mathrm{Cl}\right]} .
$$

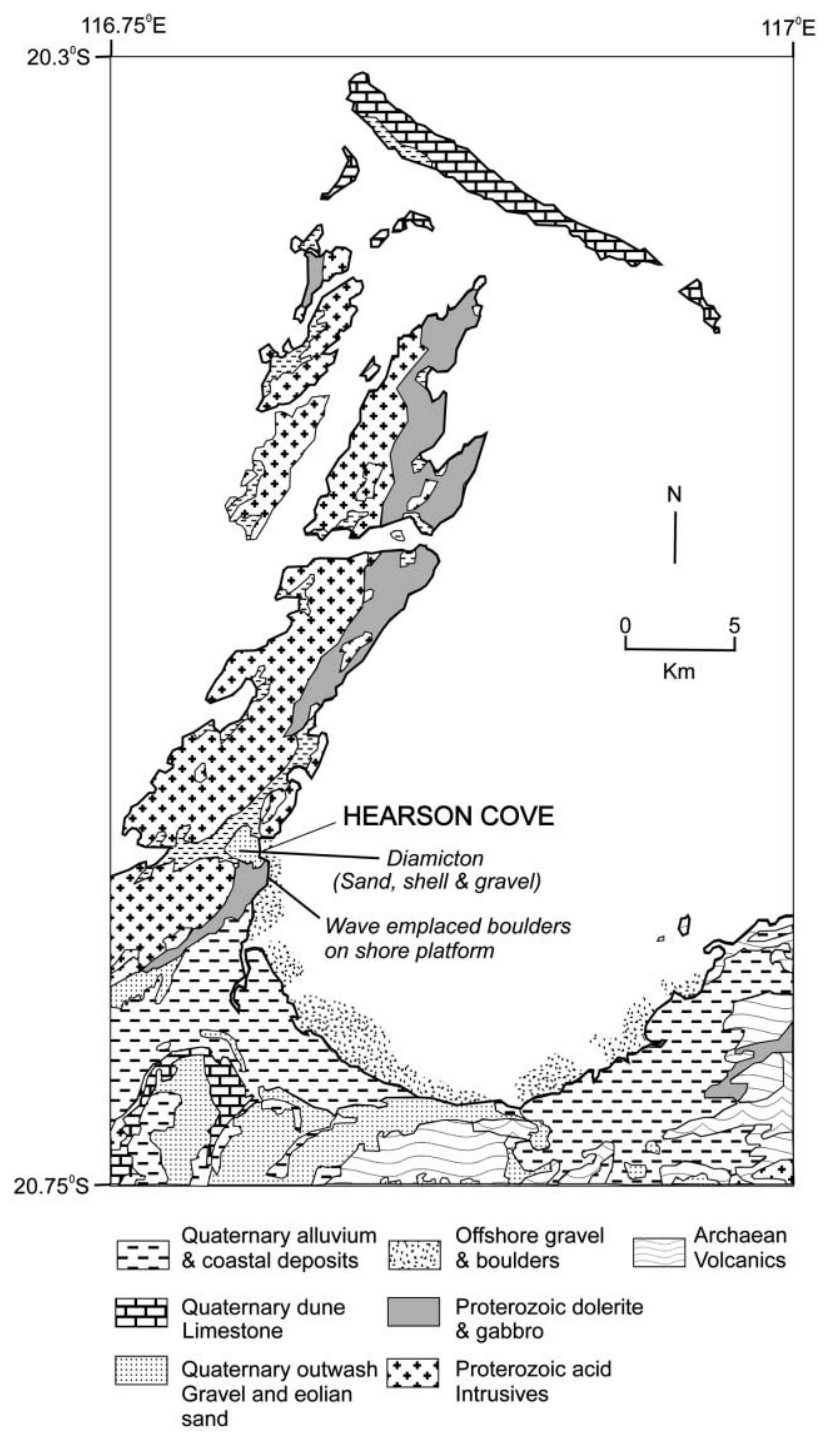

Figure 9. Geologic map of Hearsons Cove, near Karratha. 


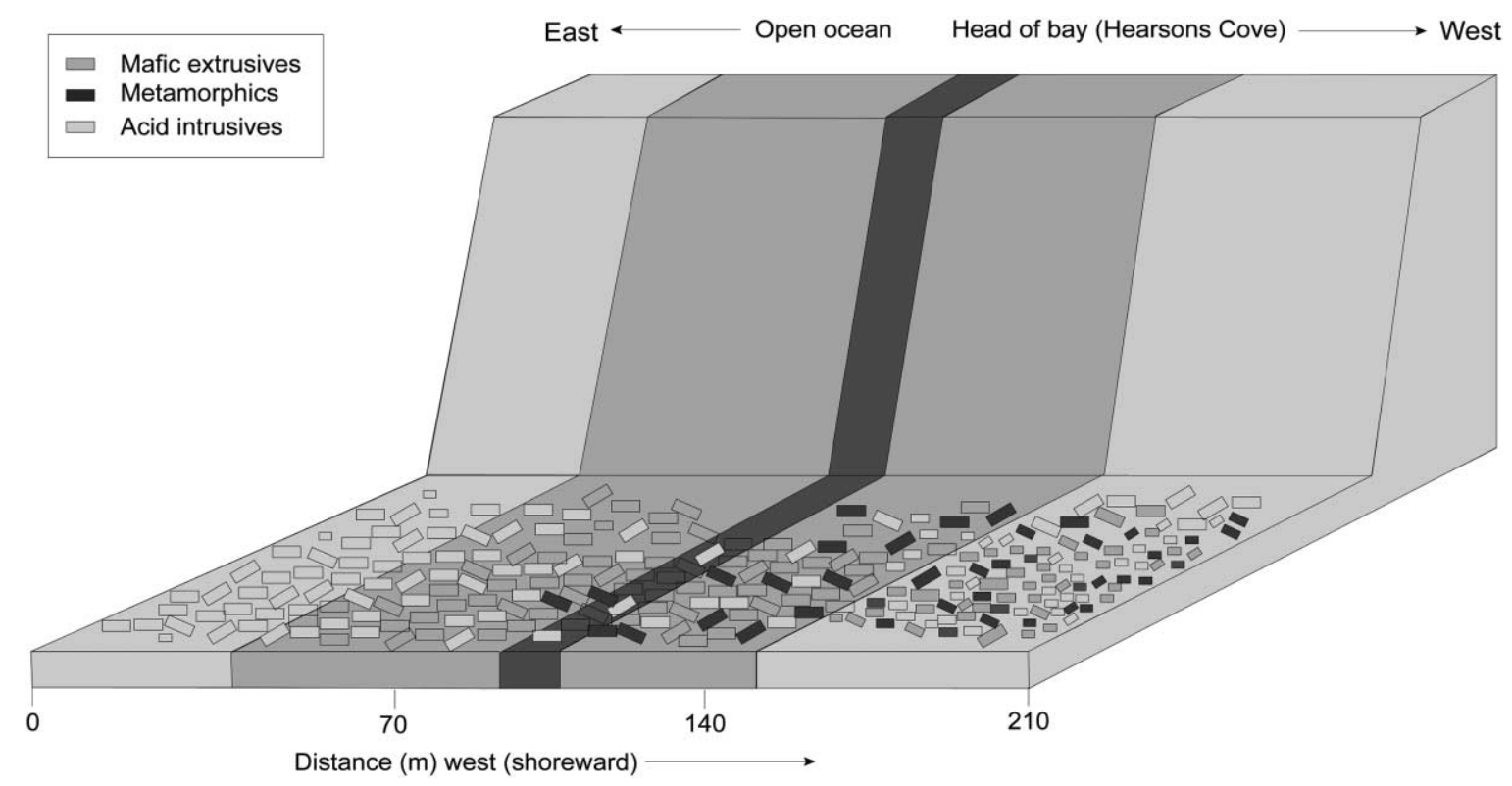

Figure 10. Geology of southern headland at Hearsons Cove and the distribution and lithology of boulders on adjacent shore platform. Note the presence of extrusive mafic and metamorphic lithology boulders adjacent to section of headland (western end) composed of acid intrusives. Note also that, except for one boulder, metamorphic boulders do not occur eastward of outcrop of metamorphics in headland.

Equation (12) can be further simplified for both tsunami and storm waves as

$$
H_{\mathrm{t}} \geq \frac{\left[\left(\rho_{\mathrm{s}}-\rho_{\mathrm{w}} / 4 \rho_{\mathrm{w}}\right) 2 a-\mathrm{Cm}(a / b)(\ddot{u} / g)\right]}{\left[\operatorname{Cd}\left(a c / b^{2}\right)+\mathrm{Cl}\right]},
$$

where $H_{\mathrm{t}}=$ height of tsunami, $u=2(g h)^{0.5}, \delta=4$, and

$$
H_{\mathrm{s}} \geq \frac{\left[\left(\rho_{\mathrm{s}}-\rho_{\mathrm{w}} / \rho_{\mathrm{w}}\right) 2 a-4 \mathrm{Cm}(a / b)(\ddot{u} / g)\right]}{\left[\mathrm{Cd}\left(a c / b^{2}\right)+\mathrm{Cl}\right]},
$$

where $H_{\mathrm{s}}=$ height of storm wave at breaking point, $u=(g h)^{0.5}$, and $\delta=1$.

Equations (13) and (14) are an improved version of Nott's (1997) equations because they incorporate the inertia force including flow acceleration. In this instance, we assume that unlike boulders submerged by water in a stream flow, water initially striking the front of the boulder, for a boulder at the shore, is not buttressed by water behind it. Flow acceleration occurs when the wave strikes the boulder and then diminishes rapidly to zero as the wave front passes and boulder motion commences. As discussed by Noji et al. (1985), the value for acceleration is difficult to ascertain, but for this study, we estimated it at $1 \mathrm{~m} / \mathrm{s}^{2}$. Noji et al. (1985) note that acceleration (ü) is relatively insignificant (as in eq. [12]) because variations in this value have little effect on the total force applied to the boulder and, hence, the wave height at the shore. Noji et al. (1985) noted that despite the insignificant change in total force resulting from variations in acceleration, it is nonetheless important to include the acceleration term in the inertia-force equation, or the computation becomes unstable.

The coefficient of mass $(\mathrm{Cm})$ was determined empirically by Noji et al. (1985) and expressed by the equation

$$
\mathrm{Cm}=1.15+1.15 \tan h[(-2.0+2.5 h / H) \mid \ddot{I} €]
$$

for $h / H<1.0$, where $h=$ depth of water in front of wave and $H=$ height of wave.

Noji et al. (1985) observed that $\mathrm{Cm}$ is a function of relative water depth $(h / H)$ and that it increases dramatically when an object is initially (during the first second) impacted by a wave or bore. After approximately one second, $\mathrm{Cm}$ diminishes rapidly to approach 0 . Once the object is completely submerged in the flow, the value of $\mathrm{Cm}$ does not make any difference to the total force because acceleration becomes negligible (Noji et al. 1985). In this study, and on the basis of equation (15), we adopt a value of $\mathrm{Cm}=1$ if we assume the transported boulder was located initially at the shoreline. 


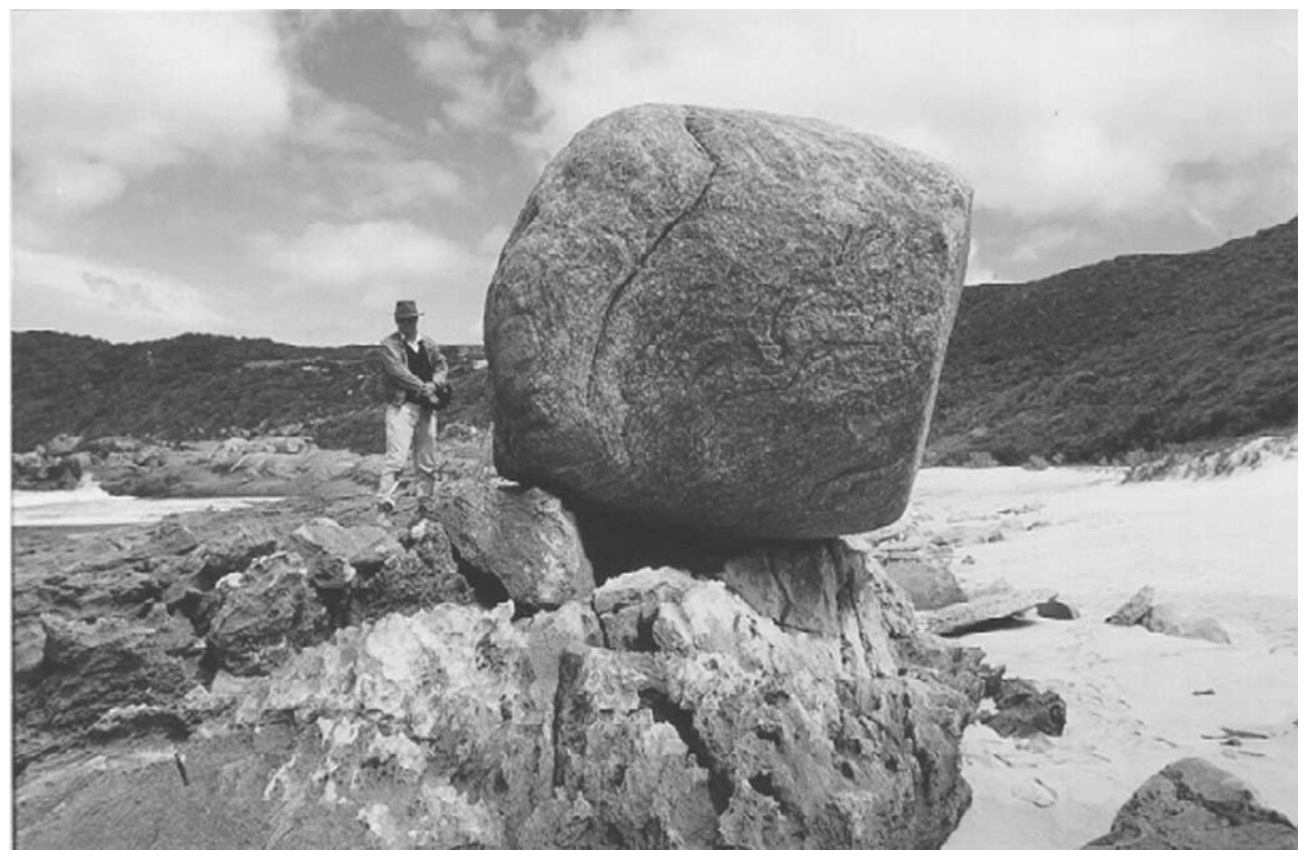

Figure 11. Granite boulder overlying sandstone beach rock at Cave Bay. Closest granite outcrop is $200 \mathrm{~m}$ alongshore at southern end of bay (background in photo).

We adopt a value of 2 for the Cd here, compared with Nott (1997), who used Cd $=1.2$. This modification concurs with experimental work (Noji et al. 1985) where Cd varies substantially with time. Noji et al. (1985) determined Cd for a block-shaped object that is similar in shape to the boulders mentioned here. For this study, we regard the value of $\mathrm{Cd}=2$ as the mean of the variations found in these experiments (Noji et al. 1985) following passage of the initial wave front.

All values of $\mathrm{Cd}, \mathrm{Cm}$, and $\ddot{u}$ appear to increase dramatically during the first second of impact by the wave front and appear to diminish rapidly afterward. Such high values, when input into equations (13) and (14), show that considerably less force is required to move boulders during the first second of wave impact because of the rapid change in momentum related to water depth. This change in momentum would initiate boulder movement, but, as shown by equations (15) and (16), much more force is then required to transport the boulders some distance inland. Because it is highly unlikely for a wave of given height to increase its force or height after the first second of impact on a boulder at the shore, more conservative values of $\mathrm{Cd}, \mathrm{Cm}$, and $\ddot{u}$ have been used in this study. As equations (13) and (14) show, a wave of greater height is required to transport a boulder some distance inland than that required to initiate movement of a boulder during the first second of wave impact. After submergence of the boulder by the wave, and if the water or flow depth is at least 0.35 grain diameters above the boulder, lift force will also act on the boulder (Einstein and El-Samni 1949).

Velocity in the drag-force equation refers to depth-averaged velocity, whereas velocity in the lift-force equation refers to bed velocity (Einstein and El-Samni 1949). Baker (1973) noted that because of flow turbulence, bed velocity during floods in stream channels is probably close to mean velocity. Costa (1983) likewise recognized that the two velocities are similar, but he increased his bed velocity by $20 \%$ to equate it to mean velocity. The highly turbulent nature of a breaking wave and bore suggests that the difference between bed and mean velocity in this situation is probably minimal. Lift force is also a minor component of the final equations for wave heights, so the two velocities (bed and mean) are assumed to be equal in this analysis.

In this study, the velocity equation incorporated into the hydrodynamic transport equation for oscillatory wind- (storm-) generated waves at breaking point is

$$
u \geq(g h)^{0.5}
$$

This equation is different from that used by Nott 
Table 1. Boulder Sizes and Heights of Waves (Tsunami and Storm) Required to Transport Boulders

\begin{tabular}{|c|c|c|c|c|c|c|}
\hline Location & $\begin{array}{c}a \text {-axis } \\
(\mathrm{m})\end{array}$ & $\begin{array}{c}b \text {-axis } \\
(\mathrm{m})\end{array}$ & $\begin{array}{c}c \text {-axis } \\
(\mathrm{m})\end{array}$ & $\begin{array}{l}\text { Volume } \\
\left(\mathrm{m}^{3}\right)\end{array}$ & $\underset{(\mathrm{m})}{\text { Tsunami }}$ & $\begin{array}{c}\text { Storm } \\
(\mathrm{m})\end{array}$ \\
\hline Leveque & 4.2 & 2.1 & 1.6 & 14.1 & .84 & 2.84 \\
\hline Leveque & 5.6 & 2.7 & 1.2 & 18.1 & 1.80 & 6.36 \\
\hline Leveque & 4.3 & 2.8 & 1.9 & 22.9 & 1.24 & 4.39 \\
\hline Leveque & 4 & 2.3 & 1.1 & 10.1 & 1.40 & 4.83 \\
\hline Leveque & 3.6 & 1.8 & .9 & 5.8 & 1.06 & 3.46 \\
\hline Quobba & 6.3 & 4.8 & 2.6 & 78.6 & 2.61 & 9.75 \\
\hline Quobba & 5.3 & 3.6 & 2.1 & 40.1 & 1.84 & 6.71 \\
\hline Quobba & 5.1 & 3.7 & 2.3 & 43.4 & 1.77 & 6.49 \\
\hline Quobba & 4.5 & 2.8 & 1.9 & 23.9 & 1.24 & 4.41 \\
\hline Quobba & 4.1 & 2.5 & 1.4 & 14.4 & 1.32 & 4.61 \\
\hline Hearson & 3.5 & 2 & 1.1 & 7.7 & 1.07 & 3.58 \\
\hline Hearson & 3 & 1.7 & .8 & 4.1 & 1.04 & 3.35 \\
\hline Hearson & 3.3 & 1.3 & .9 & 3.9 & .56 & 1.66 \\
\hline Hearson & 2.9 & 1 & .7 & 2.0 & .42 & 1.10 \\
\hline Hearson & 2.7 & .9 & .6 & 1.5 & .39 & .96 \\
\hline Cave Bay & 3 & 3 & 2.5 & 22.5 & 1.06 & 3.80 \\
\hline
\end{tabular}

Note. See text for details of derivation of equations to determine wave heights.

(1997), who, following Massel and Done (1993), used

$$
u=0.5(g h)^{0.5}
$$

Equation (16) describes the velocity (celerity) of an unbroken wave. After a wave breaks, the velocity will reduce rapidly to approach that of equation (17). Thus, boulder transport will occur somewhere between these two wave velocities. We take a conservative approach and adopt equation (16) because the movement of boulders is assumed to be initiated at the point of commencement of wave breaking and because it is difficult to derive an average orbital-wave velocity during transport of the boulder.

The velocity of a tsunami as it surges over a dry bed (the shoreline) is

$$
u=2(g h)^{0.5} .
$$

In equation (19), we consider Fukui et al.'s (1963) analysis of tsunami-bore velocity. Their equation for the velocity of a tsunami bore is

$$
u=\zeta\left\{\frac{[g(H+h)]^{0.5}}{2 H(H-\ddot{I} € \zeta)}\right\}
$$

where $H=$ height of bore, $h=$ depth of "still" water in front of bore, $\zeta=H-h$, and $\ddot{\mathrm{I}} €=$ friction factor.

Fukui et al. (1963, fig. 7, p. 75) determined the friction factor (İ€) empirically. This factor varies between $\sim 0.82$ and $\sim 1.02$ with increasing $h / H$. With this equation, $\ddot{\mathrm{I}} €$ is a critical variable in determining the velocity of a tsunami bore and the relationship between $\ddot{\mathrm{I}} €$ and $u$, where $u=\delta(g H)^{0.5}$, is given by

$$
\delta=\frac{1}{[2(1-\ddot{I} €)]^{0.5}} .
$$

The best value for Ï $€$ for this study is between the two values $\ddot{\mathrm{I}} € \approx 0.82$ when $h / H=0$ and $\ddot{\mathrm{I}} € \approx$ 1.02 when $h / H=0.5$. The boulders in our study have been transported well above sea level. If a tsunami were responsible, the wave would have transported the boulders over dry land or where $h / H>$ 0.5 and Ï $€>1.02$. As shown by equation (19), where İ $€>1.02$ and $\delta>2$, the tsunami velocity would be greater than $u=2(g H)^{0.5}$. This value appears extreme. A more conservative value of $\ddot{\mathrm{I}} €=0.875$ or $\delta=2$, being the same as that used by Nott (1997), is used here. By incorporating equation (16) into equation (14), the difference in wave height between tsunamis and storm waves required to move a given size boulder is reduced substantially compared with the equations proposed by Nott (1997).

Using these hydrodynamic transport equations, we calculate that tsunami waves between 1 and 2 $\mathrm{m}$ wave height were required to transport the boulders at Cape Leveque (table 1). Storms waves 3 to $6 \mathrm{~m}$ high at the shore were required to move the same boulders. At Quobba Point, tsunamis between 1.2 and $2.6 \mathrm{~m}$ high or storm waves between 4.4 and $9.8 \mathrm{~m}$ high at the shore are required to transport the boulders. Similarly, at Hearsons Cove, tsunamis necessary to initiate boulder movement are much smaller $(0.4-1 \mathrm{~m})$ than storm waves (1$3.6 \mathrm{~m})$. At Cave Bay, a tsunami $1 \mathrm{~m}$ high is required compared with storm waves of $3.8 \mathrm{~m}$. It is unlikely 
Table 2. Carbon 14 Results from Carbonate Deposits on Headlands and High Sand Dunes along Western Australian Coast

\begin{tabular}{|c|c|c|c|c|c|}
\hline Code & Location & Material & Situation & $\begin{array}{c}\text { Age } \\
\left({ }^{14} \mathrm{C} \text { conventional }\right)\end{array}$ & $\begin{array}{c}95.4 \%(2 \sigma) \text { calibrated } \\
\text { age range (A.D.) }\end{array}$ \\
\hline Beta 98467 & Cape Leveque & Oyster & Headland $22 \mathrm{~m}$ a.s.1 & $330 \pm 50$ & $1720-1950$ \\
\hline Beta 98468 & Cape Leveque & Shell & $30 \mathrm{~m}$ a.s.1. & $350 \pm 60$ & $1715-1950$ \\
\hline Beta 98469 & Cape Leveque & Oyster & Scabland & $330 \pm 60$ & $1750-1950$ \\
\hline Beta 98470 & Cape Leveque & Oyster & Headland $20 \mathrm{~m}$ a.s.l. & $340 \pm 50$ & $1721-1950$ \\
\hline Beta 98472 & Cape Leveque & Shell & Scabland & $1110 \pm 60$ & $1070-1440$ \\
\hline Beta 98470 & Cape Leveque & Shell & Scabland & $920 \pm 60$ & $1280-1630$ \\
\hline Beta 98471 & Cape Leveque & Oyster & Sand dune & $890 \pm 60$ & $1360-1640$ \\
\hline Beta 98478 & Point Samson & Shell & $1 \mathrm{~km}$ inland & $370 \pm 50$ & $1715-1950$ \\
\hline Beta 98482 & Point Samson & Shell & Headland & $390 \pm 60$ & $1705-1950$ \\
\hline Beta 98477 & Point Samson & Shell & Shell-rich dune & $1760 \pm 60$ & $420-860$ \\
\hline Beta 98480 & Point Samson & Shell & Big sand dune & $1310 \pm 50$ & $900-1290$ \\
\hline Beta 98481 & Point Samson & Oyster & Big sand dune & $1900 \pm 60$ & $260-690$ \\
\hline Beta 98479 & Point Samson & Shell & Big sand dune & $2410 \pm 80$ & 400-200 в.С. \\
\hline Beta 98476 & Point Samson & Shell & Sand dune & $2490 \pm 60$ & 410-80 в.с. \\
\hline Beta 98483 & Point Samson & Coral & $1 \mathrm{~km}$ inland valley & $5300 \pm 80$ & 3970-3480 в.С. \\
\hline Beta 98486 & Great Sandy desert & Shell & $\begin{array}{l}30 \mathrm{~km} \text { inland on } \\
\text { sand dune }\end{array}$ & $2310 \pm 50$ & 220-270 в.С. \\
\hline Wk 7016 & Karratha & Coral & Dune & $600 \pm 40$ & $1530-1950$ \\
\hline Wk 7017 & Karratha & Shell & $1 \mathrm{~km}$ inland & $1540 \pm 60$ & $660-1050$ \\
\hline Wk 7018 & Learnmonth & Shell & Longitudinal dune & $1350 \pm 40$ & $860-1260$ \\
\hline Wk 7019 & Learnmonth & Shell & Longitudinal dune & $5870 \pm 60$ & 4560-4230 в.С. \\
\hline Wk 6970 & Learnmonth & Shell & Longitudinal dune & $5780 \pm 70$ & 4450-3980 в.с. \\
\hline Wk 7020 & Dampier & Shell & Dune & $1890 \pm 50$ & $380-690$ \\
\hline Wk 6791 & Dampier & Shell & Dune & $610 \pm 50$ & $1520-1950$ \\
\hline Wk 6968 & Red Bluff & Worm tubes & On boulder & $620 \pm 80$ & $1500-1950$ \\
\hline
\end{tabular}

Note. Ages were calibrated and corrected for marine reservoir effect using Stuiver et al. (1998). Age ranges have relative area under probability distribution $=1.00$. Age $\left({ }^{14} \mathrm{C}\right.$ conventional $)$ is conventional or uncalibrated ${ }^{14} \mathrm{C}$ age .

that storm waves of these heights could have occurred at the shore or on the shore platforms at Cape Leveque, Quobba Point, and Cave Bay because the relatively shallow depths immediately offshore would have caused early wave breaking. For waves of this size to break at the shore, a storm surge of 1.2 times the wave height is required, and this is unlikely because such excessive surges are not possible at Cape Leveque and Quobba Point, even during the most powerful tropical cyclones. This is also the case at Cave Bay. A storm surge of $5 \mathrm{~m}$ is possible at Hearsons Cove, so it is possible that storm waves could have moved these boulders. Tsunamis appear to be the most likely wave type responsible for transporting the boulders at Cape Leveque, Quobba Point, and Cave Bay.

A tsunami approximately $2 \mathrm{~m}$ high occurred at Cape Leveque in 1977 after an earthquake in Indonesia. A tsunami of nearly $3 \mathrm{~m}$ occurred at Geraldton, south of Quobba Point, just after the 1883 Krakatau volcanic eruption. These historic tsunamis were large enough to transport the boulders at these two locations. However, the 25-m-high headland at Cape Leveque was washed over by waves, and slabs of rock greater than $0.5 \mathrm{~m}$ ( $b$-axis) were overturned at this elevation. This suggests that prehistoric tsunamis were responsible because these waves must have been approximately $5 \mathrm{~m}$ high (at shore) because tsunamis are able to run up to elevations five times their wave height (Camfield 1980). The same is true elsewhere along the Western Austrailan coast. At North West Cape, paleotsunamis also appear to be the most likely mechanism for emplacement of shells in dunes at least 12-15 $\mathrm{m}$ a.s.l. The highest historic tsunamis (1977 and 1994) here had run ups of only $4 \mathrm{~m}$, and the more recent of these transported coral blocks and marine fauna over $1 \mathrm{~km}$ inland on the western side of North West Cape. At Karratha, Point Samson, and Dampier, paleotsunamis appear to have reached heights $>10 \mathrm{~m}$ a.s.l., but historic tsunamis have reached only $2 \mathrm{~m}$ a.s.l.

\section{Chronology of Paleowave Events}

Shell and coral were radiocarbon dated at a number of the study sites along the Western Australian coast (table 2; fig. 12). All results have been calibrated using CALIB, the University of Washington Quaternary Isotope Lab carbon 14 calibration program (Stuiver et al. 1998). This program uses a radiocarbon half-life of $5568 \mathrm{yr}$ and a time-dependent global ocean reservoir correction of approximately 400 yr. The latter was corrected for the Western 


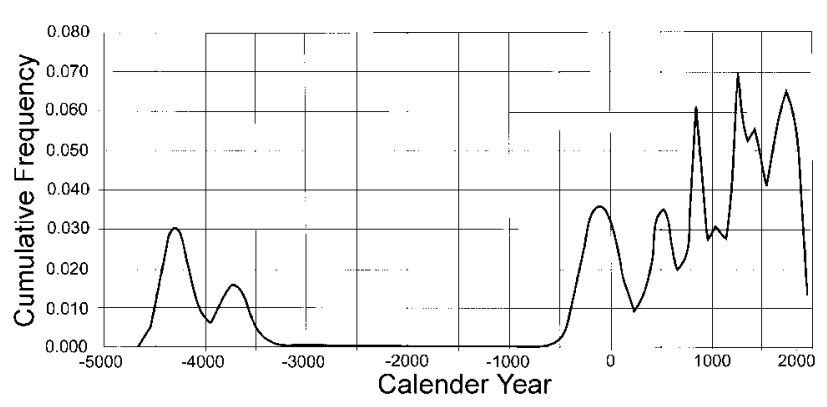

Figure 12. Cumulative probability frequency of ${ }^{14} \mathrm{C}$ ages for northwest coast of Western Australia.

Australia region by incorporating a local reservoir effect, $\delta R$, of $-3 \pm 84$ (Gillespie and Polach 1979). Figure 12 presents the cumulative frequencies of the calibrated ages. Each age was converted to a probability distribution, and the relative area under the curve was calculated using a kernel of $50 \mathrm{yr}$. These proportions were then aggregated for each century between 7000 в.P. and the present. The total area under the curve sums to 1.0 and includes 19 radiocarbon ages.

Two possible explanations account for the spread of ages. First, these ages may represent numerous events or different events at separate locations throughout the late Holocene. Second, waves may have reworked older shell and coral, and the number of events may be overestimated by the spread of ages. Hence, the youngest ages at each location may be more indicative of the timing of the events. But probably both explanations are partially correct. At some locations, there is a clear clustering of dates. At Cape Leveque, ages cluster between A.D. 1291 and 1444. There are four modern dates collected from shell scattered across the cliff top. A more recent event cannot be ruled out here, given that distinct beds of sediment can be seen in some of the deposits. When this latter event occurred is problematic. European settlement of this isolated coast occurred only in the mid-1800s. At Point Samson, most radiocarbon dates scatter between 1400 and 2200 B.P. A more recent period also cannot be ruled out. Whether the older period consists of more than one event is again uncertain because multiple layers can be discerned in tsunami deposits. This dating period also includes shell found $30 \mathrm{~km}$ inland at the limit of tsunami run up nearby in the Great Sandy Desert and farther west around Dampier and at North West Cape. There is also clear evidence for an earlier tsunami event at the time that the Holocene transgression first approached modern sea levels 5500 to $6500 \mathrm{yr}$ ago.
This event appears only at North West Cape and Point Sampson. It is also possible that contamination of the deposits by older shell has occurred and has given the deposits an older, anomalous age. If multiple events have occurred in the region, then the approximate return period for large tsunamis (run ups greater than $10 \mathrm{~m}$ ) for the northwest coast of Western Australia (Cape Leveque to North West Cape) is 400 to 500 yr. This is more frequent than the periodicity of large paleotsunamis identified for the southeast coast of Australia (Young et al. 1997), the Southern Ryukyu Island of Japan (Kawana and Nakata 1994), or the west coast of the United States and Canada (Darienzo and Peterson 1990).

\section{Possible Tsunami Sources}

Recent tsunamis in Western Australia were caused by earthquakes generated in the Timor Trench (fig. 1) and the 1883 Krakatau volcanic eruption. It is possible that the larger prehistoric tsunamis along this coast were also caused by similar mechanisms but of much larger magnitudes. Submarine landslides and bolide impacts are other possibilities. Undersea landslides usually result in localized tsunamis. The large distances over which the paleotsunami evidence exists along the Western Australian coast and the shallow continental shelf between Cape Leveque and North West Cape, where the $500-\mathrm{m}$ isobath lies over $400 \mathrm{~km}$ offshore, suggest submarine landslides are an unlikely source.

Bolide impacts could produce widespread tsunami evidence. Ward and Asphaug (2000) calculated that a generic coastal site with $180^{\circ}$ exposure and reach of $6000 \mathrm{~km}$ has a $1: 12$ chance of experiencing a 2-m tsunami and $1: 35$ chance of a 5$\mathrm{m}$ or greater amplitude tsunami in a 1000 -yr period from asteroid impact into the ocean. Thus, Perth in southwestern Western Australia has a 9.95\% chance and $3.41 \%$ chance of experiencing $2-\mathrm{m}$ and 5-m tsunami amplitudes, respectively, in a 1000-yr period from oceanic asteroid impact. A 2-m tsunami has the ability to run up to $10 \mathrm{~m}$ a.s.l. Asteroid impact into the Indian Ocean remains a possible source for the paleotsunami evidence identified along the Western Australian coast.

The evidence at several sites allows the bearing of the tsunami waves to be determined. At Cape Leveque, the imbricated boulders on the western side of the headland dip toward $260^{\circ}-270^{\circ}$, suggesting the wave or waves came from this direction. Overflow channels on top of the headland here suggest a similar wave bearing. At Point Samson, the wave or waves appear to have come from approx- 
imately $35^{\circ}$. However, while the proxy evidence is regarded as reasonable for determining the wave approach at any one location, it does not provide sufficient information to determine accurately the location of the propagating mechanisms.

\section{Conclusion}

Abundant geological evidence along $2500 \mathrm{~km}$ of coastal Western Australia shows that prehistoric wave events were considerably larger in this region than those that occurred over the past $115 \mathrm{yr}$ since European settlement. These waves had run-up heights greater than $25 \mathrm{~m}$ a.s.l. and deposited shells, corals, and lithic clasts, and they overturned rocks greater than $1 \mathrm{~m}$ diameter at this elevation. The heights attained by these waves and the size of boulders transported along shore platforms suggest that at most of the locations studied, tsunamis rather than storm waves were the most likely wave form. The proxy evidence suggests that tsunamis with run-up heights of between 10 and $30 \mathrm{~m}$ or greater have occurred with recurrence intervals of once every 4 to 5 centuries along this coast. At some locations, such as Cape Leveque, two major tsunami events have occurred over the past millennium. The source of the tsunami remains equivocal, but the potential frequency of bolide impacts into the Indian Ocean is large enough to suggest the possibility. While tsunamis have occurred historically along the Western Australian coast, the proxy evidence suggests that the prehistoric tsunamis were considerably larger. This study emphasizes the importance of examining and incorporating prehistoric evidence in risk assessments of tsunamis. Using the historic evidence alone suggests that only moderate-size tsunamis are likely along this coast. However, the prehistoric evidence shows that large tsunamis have occurred in the past and suggests that they could occur again in the future.

\section{R E F E R E N C E S C I T E D}

Atwater, B. F. 1987. Evidence for great earthquakes along the outer coast of Washington State. Science 236:942944.

Baker, V. 1973. Paleohydrology and sedimentology of Lake Misoula flooding in eastern Washington. Geol. Soc. Am. Spec. Pap. 144, p. 1-179.

Bryant, E. A., and Nott, J. F. 2001. Geological indicators of large tsunami in Australia. Nat. Hazard. 24:231249.

Bryant, E. A.; Young, R. W.; and Price, D. M. 1992. Evidence of tsunami sedimentation on the southeastern coast of Australia. J. Geol. 100:753-765.

- 1996. Tsunami as a major control on coastal evolution, southeastern Australia. J. Coast. Res. 12:831840.

Camfield, F. E. 1980. Tsunami engineering. Spec. Rep. 6. Washington, D.C., U.S. Army Corps of Engineers Coastal Engineering Research Center, 222 p.

Chappell, J.; Chivas, A.; Wallensky, E.; Polach, H. A.; and Aharon, P. 1983. Holocene palaeo-environmental changes, central to north Great Barrier Reef inner zone. J. Aust. Geol. Geophys. 8:223-235.

Costa, J. 1983. Paleohydraulic reconstruction of flash flood peaks from boulder deposits in the Colorado Front Range. Geol. Soc. Am. Bull. 94:986-1004.

Darienzo, M. E., and Peterson, C. D. 1990. Episodic tectonic subsidence of Late Holocene salt marshes, Northern Oregon central Cascadia margin. Tectonics 9:1-22.

Dawson, A. G. 1994. Geomorphological effects of tsunami run-up and backwash. Geomorphology 10:8394.

Dawson, A. G.; Long, D.; and Smith, D. E. 1988. The
Storegga slides: evidence from eastern Scotland for a possible tsunami. Mar. Geol. 82:271-276.

Einstein, H. A., and El-Samni, E.-S. A. 1949. Hydrodynamic forces on a rough wall. Rev. Mod. Phys. 21:520524.

Fukui, Y.; Nakamura, M.; Shiraishi, H.; and Sasaki, Y. 1963. Hydraulic study on tsunami. Coast. Eng. Jpn. 6: 67-82.

Gillespie, R., and Polach, H. A. 1979. The suitability of marine shells for radiocarbon dating of Australian prehistory. In Berger, R., and Suess, H. E., eds. Radiocarbon dating. Proc. 9th Int. 14C Conf. Berkeley, University of California Press, p. 404-421.

Hayne, M., and Chappell, J. 2001. Cyclone frequency during the last 5,000 yrs from Curacoa Island, Queensland. Paleogeogr. Paleoclimatol. Paleoecol. 168:201219.

Holland, G. 1997. Maximum potential intensity of tropical cyclones. J. Atmos. Sci. 54:2519-2541.

Kawana, T., and Nakata, T. 1994. Timing of Late Holocene tsunamis originating around the Southern Ryukyu Islands, Japan, deduced from coralline tsunami deposits. Jpn. J. Geogr. 103:352-376.

Lui, K. B, and Fearn, M. L. 1997. Lake sediment records of Hurricane Opal and prehistoric hurricanes from the Florida panhandle. In 22nd conference on hurricane and tropical meteorology (Fort Collins, Colo.), Proc. Am. Meteorol. Soc., p. 397-398.

Massel, S., and Done, T. 1993. Effects of cyclone waves on massive coral assemblages on the Great Barrier Reef: meteorology, hydrodynamics and demography. Coral Reefs 12:153-166.

Noji, M.; Imamura, F.; and Shuto, N. 1985. Numerical 
simulation of movement of large rocks transported by tsunamis. In Proc. IUGG/IOC Int. Tsunami Symp., p. 189-197.

Nott, J. 1997. Extremely high-energy wave deposits inside the Great Barrier Reef, Australia: determining the cause-tsunami or tropical cyclone. Mar. Geol. 141: 193-207.

. 2000. Records of prehistoric tsunamis from boulder deposits: evidence from Australia. Sci. Tsunami Hazard. 18:3-16.

Nott, J., and Hayne, M. 2001. High frequency of "supercyclones" along the Great Barrier Reef over the past 5,000 years. Nature 413:508-512.

Stuiver, M.; Reimer, P. J.; Bard, E.; Beck, J. W.; Burr, G. S.; Hughen, K. A.; Kromer, B.; et al. 1998. INTCAL98 radiocarbon age calibration, 24000-0 cal PB. Radiocarbon 40:1041-1083.

Sussmilch, C. A. 1912. Note on some recent erosion at Bondi. J. Proc. R. Soc. New South Wales 46:155-158.

Ward, S. N., and Asphaug, E. 2000. Asteroid impact tsunami: a probabilistic hazard assessment. Icarus 145: 64-78.

Young, R. W.; Bryant, E. A.; and Price, D. M. 1996. Catastrophic wave (tsunami?) transport of boulders in southern New South Wales, Australia. Z. Geomorph. 40:191-207.

Young, R. W.; Bryant, E. A.; Price, D. M.; Dilek, S. Y.; and Wheeler, D. J. 1997. Chronology of Holocene tsunamis on the southeastern coast of Australia. Trans. Jpn. Geomorphol. Union 18:1-19. 